\title{
Development and application of Participatory Integrated Assessment software to support local/regional impact and adaptation assessment
}

\section{Guest Editorial}

Holman, IP ${ }^{1 \bowtie}$, Rounsevell, M.D.A. ${ }^{2}$, Berry, P.M. ${ }^{3}$ and Nicholls, R.J ${ }^{4}$.

${ }^{1}$ Natural Resources Department, Cranfield University, UK

${ }^{2}$ School of Geosciences, University of Edinburgh, UK

${ }^{3}$ Environmental Change Institute, Oxford University Centre for the Environment, UK

${ }^{4}$ School of Civil Engineering and the Environment, University of Southampton, UK

Corresponding author: I.P. Holman

Cranfield University

Cranfield

Bedford MK43 0AL

United Kingdom

Tel: +44 (0) 1234750111 Ext. 2764

Fax: +44 (0) 1234752970

Email: i.holman@cranfield.ac.uk

The reality of climate change in the UK is rarely questioned, as a consensus has emerged amongst a wide range of national to local environmental and resource policy makers and stakeholders that climate change has been sufficiently demonstrated in a number of sectors (Shackley and Deanwood, 2002; Turnpenny et al., 2004). Decision makers and other interested citizens now need reliable science-based information to help them respond to the risks of climate change impacts and opportunities for adaptation (Turnpenny et al., 2004). However, these impacts will be in addition to or concurrent with those associated with continuing socio-economic and political changes (Nakicenovic and Swart, 2000). The impact of climate change therefore needs to be evaluated in a holistic or integrated assessment of the effects of our changing future. Integrated assessment, which is an interdisciplinary process that combines, interprets, and communicates knowledge from diverse scientific disciplines from the natural, engineering and social 
sciences to investigate and understand causal relationships within and between complicated systems, provides a tool to develop the information resources required.

However, the scale at which stakeholders require such information for adaptation assessment is rarely the global or national scale needed for climate policy (Turnpenny et al., 2004), but rather at regional and local scales (Shackley and Deanwood, 2002). The 'Regional Climate Change Impact and Response Studies in East Anglia and North West England' (RegIS) study (Holman et al, 2005 a \& b) was one of the first (sub-national) regional Integrated Assessments (IAs) in Europe. RegIS developed and applied a methodology for stakeholder-led, regional climate change impact assessment that explicitly evaluated local to regional (sub-national) scale impacts and adaptation options, and cross-sectoral interactions driving broad-scale landscape change in agriculture, biodiversity, coastal and floodplain systems and water resources.

Providing results or interpretations to stakeholders based on the outputs of particular simulations of an IA is not sufficient to test the sensitivity of the system, to engender organizational or behavioural change or to enable knowledge creation as a learning process. It represents a one-way flow of information, rather than a two-way iterative process of dialogue and exploration of "what if' s". More interactive IA systems are needed that allow stakeholders to develop their understanding and test ideas, based upon their own hypotheses.

Unfortunately of the more than 65 climate change IA models (Hisschemöller et al., 2001), most have unacceptably long runtimes for allowing rapid simulation and interactive engagement with the IA. It was to overcome this obstacle that the two-year RegIS2 study (Holman and de Vries, 2005) was born- its aim being to investigate and develop the use of computationally simpler modelling techniques, so called 'metamodels' or 'reduced form models' (Carmichael et al. 2004), within a user friendly interface (the 'Regional Impact Simulator', which is now available from the UK Climate Impacts Programme website - www.ukcip.org.uk) to make the RegIS IA methodology available to the wider stakeholder community. Underpinning the development of the Regional Impact Simulator was the need for clear user interfaces, explicit recognition of uncertainty, transparency in model performance and operation, the value and importance of stakeholder 'lay insight' and the need for the interface to provide a mediating focus for the dialogue between the research and stakeholder communities within a process of mutual learning and guidance (Turnpenny et al., 2004).

Rather than report on each of the sectors within the Regional Impact Simulator individually, which rather goes against the integration concept of RegIS, each paper in this Special Issue has been selected to provide an integrated view of an issue which spans more than one sector. 
- Holman et al. (this issue) begin by describing the concepts for undertaking regional integrated climate change assessment and provide an overview of the development of the 'Regional Impact Simulator';

- Mokrech et al. (this issue) describe the flooding impacts (areas flooded, people affected and economic damages) as a consequence of climate change and socio-economic development;

- Audsley et al. (this issue) describe the impact of future socio-economic and climate changes on regional agricultural land use and the consequences for the wider environment;

- Henriques et al. (this issue) integrate the effects of socio-economic and climate changes on water resources, and describe the implications for water resource availability and agricultural irrigation;

- Harrison et al. (this issue) integrate water resources and biodiversity to investigate the implications for potential future wetland habitat change;

- Richards et al. (this issue) describe the implications of climate change on coastal and fluvial ecosystems and the potential for adaptation, including under different socio-economic futures;

- Holman and Harman (this issue) evaluate the Regional Impact Simulator from the perspective of the stakeholder community to assess whether the tool is worthwhile and useful.

Improving the adaptive capacity of individuals, groups or organizations requires communicating climate change information and building awareness of potential impacts at an appropriate regional level (Adger et al., 2005). The Regional Impact Simulator is a vehicle for communication, training, forecasting and experimentation (Welp, 2001), whose usefulness is enhanced by the integrated assessment approach which enables stakeholders to explore / understand the interactions between different sectors, rather than viewing their own area in isolation. It is therefore hoped that the Regional Impact Simulator will contribute to the UK Government's objective of a well adapted UK by building the capacity of UK decision-makers to understand the climate and socio-economic impacts and how these might be reduced by various adaptation options. Interactive tools such as the Regional Impact Simulator should result in regional scale decision-making and policy formulation which takes due account of the impacts of future climate and socio-economic change.

\section{References:}

Adger WN, Arnell NW, Tompkins EL (2005) Successful adaptation to climate change across scales. Global Environmental Change 15: 77-86

Audsley E, Pearn KR, Harrison PA, Berry PM (This issue) The impact of future socio-economic and climate changes on agricultural land use and the wider environment in East Anglia and North West England using a metamodel system. Climatic Change 90(1-2), 57-88

Carmichael J, Tansey J, Robinson J (2004). An integrated assessment modelling tool. Global Environmental Change 14, 171-183 
Harrison, P.A., Berry, P.M., Henriques, C. and Holman, I.P. (2008). Impacts of socioeconomic and climate change scenarios on wetlands: linking water resources and biodiversity meta-models. Climatic Change 90(1-2), 113-139

Henriques C, Holman IP, Audsley E, Pearn K (2008) An interactive multi-scale integrated assessment of future regional water availability for agricultural irrigation in East Anglia and North West England. Climatic Change 90(1-2), 89-111

Hisschemöller, M, Tol, R.S.J. \& Vellinga, P. (2001). The relevance of participatory approaches in integrated environmental assessment. In Integrated Assessment, .2(2), 57-72

Holman IP, Harman J (2008) Preliminary evaluation of the benefits of a participatory regional integrated assessment software. Climatic Change 90(1-2), 169-187

Holman IP, Rounsevell MDA, Cojacaru G, Shackley S, McLachlan C, Audsley E, Berry PM, Fontaine C, Harrison PA, Henriques C, Mokrech M, Nicholls RJ, Pearn KR, Richards JA (2008) The concepts and development of a participatory regional integrated assessment tool. Climatic Change $90(1-2), 5-30$

Holman I.P. and de Vries T.T. (eds.) (2005). 'Development of a metamodel tool for regional integrated climate change management (RegIS2)'. Final Report for Project No. CC0362, Department for Environment, Food and Rural Affairs, London.

Holman I.P., Rounsevell M.D.A., Shackley S., Harrison P.A., Nicholls R.J., Berry P.M. and Audsley E. (2005a). A regional, multi-sectoral and integrated assessment of the impacts of climate and socioeconomic change in the UK: I Methodology. Climatic Change, 71, 9-41.

Holman, I.P. Nicholls, R.J. Berry, P.M. Harrison, P.A. Audsley, E. Shackley, S. and Rounsevell, M.D.A. (2005b). A regional, multi-sectoral and integrated assessment of the impacts of climate and socioeconomic change in the UK: II Results. Climatic Change, 71, 43-73.

Mokrech M, Nicholls RJ, Richards JA, Henriques C, Holman IP, Shackley S (2008) Regional impact assessment of flooding under future climate and socio-economic scenarios for East Anglia and North West England. Climatic Change 90(1-2), 31-55

Nakicenovic, N. and Swart, R. (eds.) (2000). Special Report on Emissions Scenarios. A Special report of Working Group III of the Intergovernmental Panel on Climate Change. Intergovernmental Panel on Climate Change, Cambridge University Press Cambridge, pp. 599.

Richards JA, Mokrech M, Berry PM, Nicholls RJ (2008) Regional assessment of climate change impacts on coastal and fluvial ecosystems and the scope for adaptation. Climatic Change 90(1-2), $141-167$

Shackley, S. and Deanwood, R. (2002). Stakeholder perceptions of climate change impacts at the regional scale: Implications for the effectiveness of regional and local responses. Journal of Environmental Planning and Management 45(3), 381-402. 
Turnpeny, J., Haxeltine, A. \& O'Riordan, T. (2004). A scoping study of user needs for Integrated Assessment of climate change in the UK context: Part 1 of the development of an Interactive Integrated Assessment Process. Integrated Assessment 4(4), 283-300.

Welp M (2001). The use of Decision Support Tools in participatory river basin management. Phys. Chem. Earth (B) 26(7-8): 535-539. 